Article

\title{
Two Chemically Stable Cd(II) Polymers as Fluorescent Sensor and Photocatalyst for Aromatic Dyes
}

\author{
Jun Wang ${ }^{1, *}$, Jian Wu ${ }^{2}$, Lu Lu ${ }^{1}$, Ai-Qing Ma ${ }^{3, *}$, Wan-Shan $\mathrm{Hu}^{3}$, Wei-Ping Wu ${ }^{1}, \mathrm{Yu} \mathrm{Wu}^{1}$, \\ Yan-Chun Sun ${ }^{1}$, Amita Singh ${ }^{4}$ and Abhinav Kumar ${ }^{4, *}$ \\ 1 School of Chemistry and Environmental Engineering, Sichuan University of Science \& Engineering, \\ Zigong 643000, China; lulusczg@126.com (L.L.); weipingwuzg@126.com (W.-P.W.); wuyuhlj@163.com (Y.W.); \\ sunyanchun1120@163.com (Y.-C.S.) \\ 2 Guangxi Key Laboratory of Chemistry and Engineering of Forest Products, \\ Guangxi University for Nationalities, College of Chemistry and Chemical Engineering, Nanning 530006, \\ China; wujian2007gx@126.com \\ 3 Dongguan Key Laboratory of Drug Design and Formulation Technology, \\ Key Laboratory of Research and Development of New Medical Materials of Guangdong Medical University, \\ School of Pharmacy, Guangdong Medical University, Dongguan 523808, China; wanshanhu2018@126.com \\ 4 Department of Chemistry, Faculty of Science, University of Lucknow, Lucknow 226 007, India; \\ singhamita3010@gmail.com \\ * Correspondence: scwangjun2011@126.com (J.W.); maqandght@126.com (A.-Q.M.); \\ kumar_abhinav@lkouniv.ac.in (A.K.); Tel./Fax: +86-0769-22-896-560 (A.-Q.M.)
}

Received: 24 January 2018; Accepted: 23 February 2018; Published: 7 March 2018

\begin{abstract}
Two new 2D Cd(II)-based coordination polymers (CPs), viz. $\left[\mathrm{Cd}_{2}\left(\mathrm{H}_{2} \mathrm{~L}\right)_{2}\left(2,2^{\prime} \text {-bipy) }\right)_{2}\right]$ (1) and $\left[\mathrm{Cd}(\mathrm{L})_{0.5}\right.$ (phen) $\left.\cdot 0.5 \mathrm{H}_{2} \mathrm{O}\right](2)$, have been constructed using ethylene glycol ether bridging tetracarboxylate ligand 5,5' $\left(4,4^{\prime}\right.$-phenylenebis(methyleneoxy)) diisophthalic acid $\left(\mathrm{H}_{4} \mathrm{~L}\right)$. Both CPs behaved as profound fluorescent sensor for $\mathrm{Fe}^{3+}$ ion and nitro-aromatics (NACs), specifically 2,4,6-trinitrophenol (TNP). The stability at elevated temperature and photocatalytic behaviors of both 1 and 2 for photo-decomposition of aromatic dyes have also been explored. An attempt has been made to explore the plausible mechanism related with the decrease in fluorescence intensity of $\mathbf{1}$ and $\mathbf{2}$ in presence of NACs using theoretical calculations. Additionally, the probable mechanism of photo catalysis by $\mathbf{1}$ and $\mathbf{2}$ to photo-degrade aromatic dyes has been explained using density of states (DOS) calculations.
\end{abstract}

Keywords: chemosensor; photocatalyst; polymer; DOS

\section{Introduction}

The existence of traces of hazardous chemicals (HCs) inculcating both organic as well as inorganic compounds after their certain threshold limit in the environment is imposing detrimental effect on environment as well as living creatures [1-4]. Among organic compounds, the common nitro-aromatic explosives, in particular 2,4,6-trinitrophenol (TNP), can cause a menace due to its explosive nature. It also poses severe health problems to humans and affects the ground water/soil as well [5-10]. In addition, in the inorganic cations category, $\mathrm{Fe}^{3+}$ is vital for the formation of hemoglobin and muscle and additionally improves brain functions [11]. The excess or deficiency of $\mathrm{Fe}^{3+}$ is so detrimental that it may lead to damage to nucleic acids and proteins [11-15]. Thus, a highly effective and fast technique to detect trace amount of $\mathrm{Fe}^{3+}$ over other metal ions is of much concern. Nowadays, luminescent coordination polymers (CPs) with open coordination sites have attracted much attention, as these can efficiently interact with various metal ions and hence offer a useful methodology for the development 
of luminescence sensors and heterogeneous catalysts [16-20]. The incorporation of carboxylate groups is an effective way to construct CPs with open coordination sites [21]. Cohen et al. reported a series of CPs based on 2-phenylpyridine-5, $4^{\prime}$-dicarboxylicacid (dcppy) and was the first group who performed cyclometalation post-synthetic modification reactions on these CPs [21].

The aromatic organic compounds deployed as dyes in the past few years have been widely used as chemicals in many industries, but they are hard to biodegrade, thereby causing serious environmental pollution [22]. Thus, the degradation of dye molecules into relatively less hazardous products is very important for environmental protection. Mostly CPs behave like insulators, but some semiconducting CPs are also reported and it has theoretically been proposed that syntheses of numerous CPs displaying semiconducting properties are possible, which can catalyze the photo-degradation of aromatic dyes [23-29]. Therefore, the proper design and synthesis of porous CPs displaying multifarious molecule-based applications is highly desirable but it is still a huge challenge to chemists [30-35].

Keeping these characteristics of CPs in mind and in our incessant pursuit for the designing and syntheses of new CPs that can display dual properties, i.e., as fluorescent sensor for nitro-aromatics/ions and photocatalysts for the photo-decomposition of aromatic dyes [3,4], in the presented work, we used an unexploited $5,5^{\prime}$-(4,4'-phenylenebis(methyleneoxy)) diisophthalic acid $\left(\mathrm{H}_{4} \mathrm{~L}\right)$ to fabricate $\mathrm{Cd}(\mathrm{II})$-based CPs comprising of 2,2'-bipyridyl and 1,10-phenanthroline as ancillary ligand. The CPs reported in the presented investigation comprises a 2D framework and have been used as a fluorescent sensor for $\mathrm{Fe}^{3+}$ ions and 2,4,6-trinitrophenol (TNP). In addition, the photocatalytic properties of these CPs have been explored for the photo-decomposition of aromatic dyes, viz. methyl violet (MV) and Rhodamine B (RhB). The results of these investigations are presented herein.

\section{Materials and Method}

\subsection{Chemicals and Instrumentation}

All chemicals were obtained from commercial sources and used without further purification. All the measurements have been performed on equipment mentioned in our previous report [31].

\subsection{X-ray Crystallography}

The intensity data for single crystalshave been collected on Bruker SMART APEX diffractometer (Bruker, WI, USA) using graphite monochromated $\mathrm{MoK} \alpha$ radiation $(\lambda=0.71073 \AA$ ) by using an $\omega$-scan technique. For both structures, the absorption effect intensities were corrected using SADABS. The structures were solved by direct method (SHLEXS-2014, Sheldrick, G.M, England, UK) and refined using full-matrix least-squares procedure based on $F^{2}$ (Shelxl-2014) [36]. All non-hydrogen atoms were refined anisotropically while hydrogen atoms were placed onto calculated positions and refined using a riding model. Crystallographic details and selected bond dimensions for $\mathbf{1}$ are listed in Tables S2 and S3. CCDC number: 1817769-1817770.

\subsection{Synthesis of $\left[C d_{2}\left(\mathrm{H}_{2} \mathrm{~L}\right)_{2}\left(2,2^{\prime}-\text { bipy }\right)_{2}\right]$}

A mixture of $\mathrm{H}_{4} \mathrm{~L}(0.05 \mathrm{mmol}, 0.027 \mathrm{~g}), 2,2^{\prime}$-bipy $(0.019 \mathrm{~g}, 0.1 \mathrm{mmol}), \mathrm{Cd}\left(\mathrm{NO}_{3}\right)_{2} \cdot 4 \mathrm{H}_{2} \mathrm{O}(0.15 \mathrm{mmol}$, $0.046 \mathrm{~g}$ ) and $6 \mathrm{~mL}$ of 1:1 (v/v) acetonitrile: $\mathrm{H}_{2} \mathrm{O}$ mixture was stirred for $30 \mathrm{~min}$ and then transferred and sealed in a $25 \mathrm{~mL}$ Teflon-lined reactor and heated to $120^{\circ} \mathrm{C}$ for $72 \mathrm{~h}$. Thereafter, the reactor was cooled to room temperature at a rate of $5^{\circ} \mathrm{C} / \mathrm{h}$ to obtain yellow block crystals of $\mathbf{1}$ in $71 \%$ yield based on cadmium. IR: 3068(m); 1702(m); 1662(vs); 1531(vs); 1434(vs); 1388(m); 1274(m); 1170(m); 1023(v); 817(m); 759(v); 725(m). 


\subsection{Synthesis of $\left[\mathrm{Cd}(\mathrm{L})_{0.5}(\right.$ phen $\left.) \cdot 0.5 \mathrm{H}_{2} \mathrm{O}\right]$}

The synthesis procedure of $\mathbf{2}$ was analogous to that of $\mathbf{1}$, except that 2,2'-bipy was replaced by phen $(0.1 \mathrm{mmol}, 0.020 \mathrm{~g})$. Colorless block crystals of 2 were obtained in $64 \%$ yield based on cadmium. IR: 3068(m) (Figure S1); 1673(m); 1660(vs); 1542(vs); 1433(vs); 1371(m); 1262(m); 1170(m); 1039(v); 815(m); 756(v); 723(m).

\subsection{Computational Protocols}

The plausible mechanism related with the decline in emission intensity of CPs $\mathbf{1}$ and $\mathbf{2}$ in the presence of nitro-aromatics have been proposed with the aid of density functional theory (DFT) calculations. For this the nature of Highest Occupied Molecular Orbital (HOMO) and (Lowest Unoccupied Molecular Orbital) LUMO of different analytes, CPs $\mathbf{1}$ and $\mathbf{2}$ have been assessed through geometry optimization which were calculated using the B3LYP exchange-correlation functional $[37,38]$. The $6-31 G^{* *}$ basis set for all the atoms except $\mathrm{Cd}$ was used for geometry optimization. For $\mathrm{Cd}$, CEP-121G basis set was employed. All the calculations were performed using Gaussian 09 program (Burant, J.C. et al., Gaussian, Inc., Wallingford, CT, USA) [39]. GaussSum 3.1 (Burant, J.C. et al. Gaussian, Inc.) was used to obtain density of state (DOS) plots [40].

\section{Results and Discussion}

\section{1. $\left[C d_{2}\left(\mathrm{H}_{2} \mathrm{~L}\right)_{2}\left(2,2^{\prime}-\text { bipy }\right)_{2}\right]$}

Single-crystal X-ray diffraction analysis revealed that the CP $\mathbf{1}$ crystallizes in monoclinic space group $P 22_{1} / c$ and possess a $2 \mathrm{D}$ layer structure. The asymmetric unit consists of twoindependent $\mathrm{Cd}^{2+}$ ions, two partially deprotonated $\mathrm{H}_{2} \mathrm{~L}$ ligands and two bipy ligands (Figure 1a). The $\mathrm{Cd} 1$ ion possess a distorted octahedral coordination geometry where each $\mathrm{Cd} 1$ ion is coordinated to two $\mathrm{N}$ atoms from one 2,2'-bipy ligand and four $\mathrm{O}$ atoms from two partially deprotonated $\mathrm{H}_{2} \mathrm{~L}$ ligands (Scheme $\mathrm{S} 1 \mathrm{a}, \mathrm{b}$ ). The carboxyl groups of the $\mathrm{H}_{4} \mathrm{~L}$ ligand display two types of coordination modes, viz. chelating and monodenate modes. The two $\mathrm{Cd} 1$ ions are connected by two carboxylate groups in an alternative chelating and monodenate mode to form a binuclear unit [41]. In the unit, the distance between the two Cd(II) ions is $8.173 \AA$. Cd2 is hepta-coordinated and the seven-coordinated geometry is satisfied by two $\mathrm{N}$ atoms from one 2,2'-bipy ligand and five $\mathrm{O}$ atoms from two partially deprotonated $\mathrm{H}_{2} \mathrm{~L}$ ligands (Scheme $\mathrm{S} 1 \mathrm{a}, \mathrm{b}$ ). It is noteworthy that $\mathrm{H}_{4} \mathrm{~L}$ ligand is partially deprotonated with two carboxylic groups connect to four $\mathrm{Cd}(\mathrm{II})$ atoms, which may function as the potential active site (see Figure 1b). Interestingly, there are uncoordinated carboxyl groups pointing to the interior region of pores [10] (Figure $1 \mathrm{~b}$ ). Each $\mathrm{L}^{4-}$ ligand links four Cd(II) ions to give rise to a two-dimensional (2D) layer (Figure $1 \mathrm{~b}$ ). When viewed along $b$ axis, the two-dimensional layer looks like a wavy chain, which is decorated by the 2,2'-bipy ligands. 


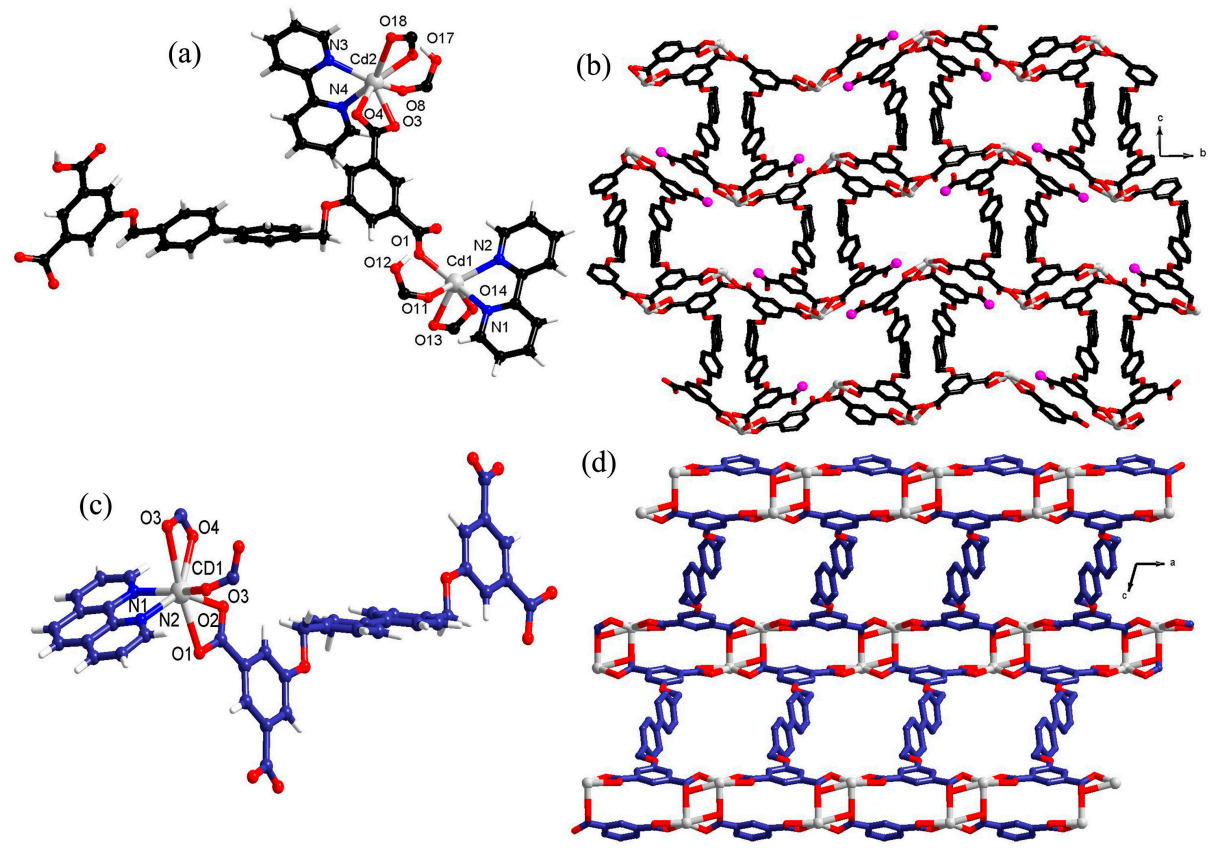

Figure 1. (a) The view of local coordination geometry of $\mathrm{Cd}(\mathrm{II})$ center and ligand in 1 . (b) The 2D layer in 1 as viewed slightly off the $b$ axis. The hydrogen atoms have been omitted for clarity; the uncoordinated carboxyl groups pointing to the interior of pores (pink color). (c) The local coordination environment around $\mathrm{Cd}(\mathrm{II})$ in 2 . The hydrogen atoms have been omitted for clarity. (d) The 2D ladder-like layered architecture in 2.

\section{2. $\left[\mathrm{Cd}(\mathrm{L})_{0.5}(\right.$ phen $\left.) \cdot 0.5 \mathrm{H}_{2} \mathrm{O}\right]$}

The single crystal X-ray diffraction analysis indicates that complex 2 also comprises a 2Dlayer structure. Within the asymmetric unit, there is one independent $\mathrm{Cd}^{2+}$ ion, half $\mathrm{L}^{4-}$ ligand, a phen ligand and a half free water molecule. As presented in Figure $1 \mathrm{c}$, the $\mathrm{Cd}(\mathrm{II})$ ion is coordinated to two $\mathrm{N}$ atoms of phen ligand and five $\mathrm{O}$ atoms from one deprotonated $\mathrm{H}_{4} \mathrm{~L}$ ligand thereby forming a pentagonal bipyramid coordination geometry around Cd(II). The carboxylate groups of $\mathrm{L}^{4-}$ ligand adopt $\mu_{2}-\eta^{1}: \eta^{1}$ chelating and $\mu_{2}-\eta^{2}: \eta^{1}$ bridging modes, which generated a 2D ladder-like layer (Scheme S1c and Figure 1d).

\subsection{Luminescence Sensing}

The structure of 1 was determined by single crystal X-ray diffraction analysis and characterized by IR spectroscopy and thermogravimetric analysis (Figures S1 and S2). The solid-state luminescent properties of CPs 1 and 2 and $\mathrm{H}_{4} \mathrm{~L}$ ligandwere examined at room temperature (Figure S3). Since both 1 and 2 are comprisied of $\mathrm{d}^{10}$ configuration based $\mathrm{Cd}^{2+}$ ions, they both show strong emission bands at $405 \mathrm{~nm}$ and $388 \mathrm{~nm}\left(\lambda_{\mathrm{ex}}=290 \mathrm{~nm}\right)$, respectively, which can be ascribed to the $\pi^{*} \rightarrow \pi$ or $\pi^{*} \rightarrow \mathrm{n}$ transitions corresponding to the $\mathrm{H}_{4} \mathrm{~L}$ ligand $\left(\lambda_{\mathrm{e}}=345 \mathrm{~nm} ; \lambda_{\mathrm{ex}}=290 \mathrm{~nm}\right)$ [42]. The appropriate luminescent properties are the prerequisite for a $\mathrm{CP}$ to behave as luminescent sensors to detect metal ions. Since the detection of metal ions is usually conducted in liquid phase, various solvents are chosen to test their influences on the initial luminescence of the CPs. It was observed that varied samples $\mathrm{M}^{\mathrm{Z}} @ \mathbf{1} / \mathbf{2}$ prepared by suspending the CPs $\mathbf{1 / 2}$ in aqueous solutions of different metal nitrates $\left(\mathrm{M}\left(\mathrm{NO}_{3}\right)_{\mathrm{x}}\right)$ exhibited noticeably diversified photoluminescence properties (Figure $\left.\mathrm{S} 4\right)$. Among the different systems, $\mathrm{Al}^{3+} @ 2$ displayed small enhancement in luminescence (Figure 2d and Figure S5). Notably, the luminescent intensities of both $\mathbf{1}$ and $\mathbf{2}$ were selectively quenched in presence of $\mathrm{Fe}^{3+}$ ions. Additionally, it was observed that with rise in concentration of $\mathrm{Fe}^{3+}$, the emission intensities of both $\mathbf{1}$ and 2alleviated (Figure 2b,e). To examine the sensitivity of CPs $\mathbf{1}$ and $\mathbf{2}$ towards $\mathrm{Fe}^{3+}$ ion, 
the concentration gradient experiments were executed by varying concentrations of $\mathrm{Fe}^{3+}$ solutions in the concentration range from 0 to 500 and / or $600 \mathrm{ppm}$ (Figure 2b,e). These experiments indicated that luminescence intensities of $\mathrm{Fe}^{3+} @ \mathbf{1} / \mathbf{2}$ progressively decreased with rise in concentration of $\mathrm{Fe}^{3+}$ [43-46].
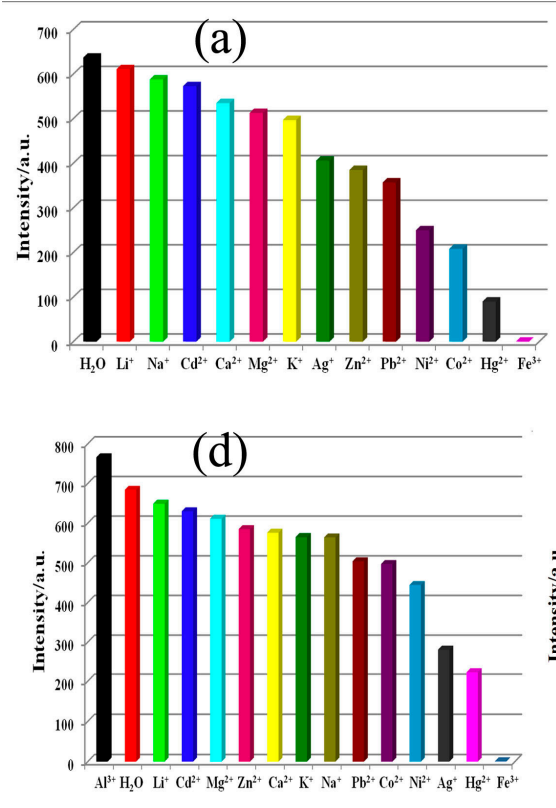

(b)

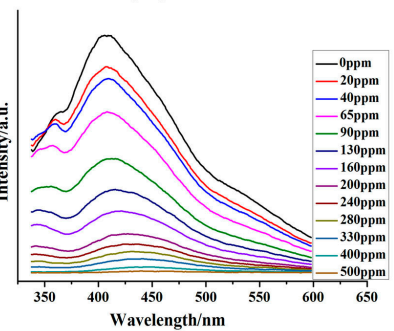

(e)

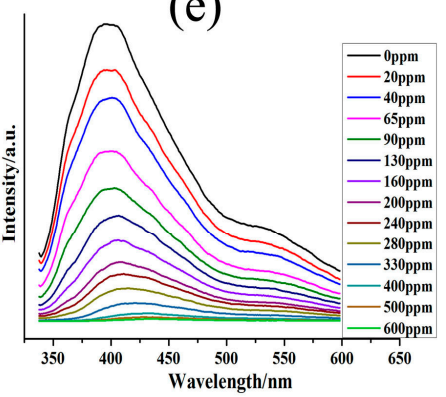

(c)
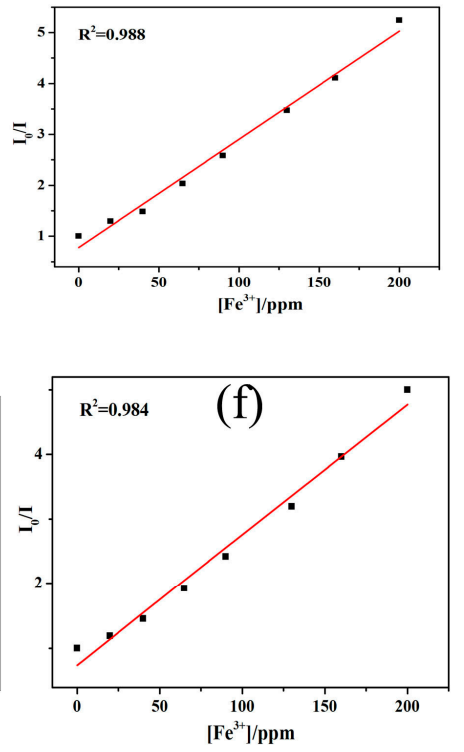

Figure 2. (a) The photoluminescence intensity of 1 dispersed in different metal ions solutions $\left(\lambda_{\mathrm{ex}}=280 \mathrm{~nm}\right)$; (b) the emissive response spectra of $\mathbf{1}$ for aqueous $\mathrm{Fe}^{3+}$ solution with different concentrations; (c) the Stern-Volmer plot for $\mathrm{Fe}^{3+}$ in presence of $\mathbf{1}$; (d) the Photoluminescence intensity of $\mathbf{2}$ dispersed in different metal ions solutions $\left(\lambda_{\mathrm{ex}}=280 \mathrm{~nm}\right)$; (e) the emissive response spectra of 2 for aqueous $\mathrm{Fe}^{3+}$ solution with different concentrations; and (f) the Stern-Volmer plot for $\mathrm{Fe}^{3+}$ in presence of 2 .

Moreover, interesting results have been obtained with $\mathrm{CP} \mathbf{1}$. The addition of $\mathrm{Fe}^{3+}$ ions to 1 results in disappearance of the original emission band (Figure 2b). The disappearance of the band can be explained on the basis that $\mathrm{Fe}^{3+}$ ions interact with the $-\mathrm{COOH}$ groups of the $\mathrm{H}_{4} \mathrm{~L}$ ligand in $\mathbf{1}$ as well as the intramolecular charge-transfer phenomenon [46].

The Stern-Volmer plots for $\mathrm{Fe}^{3+}$ are almost linear at low concentrations with the $K_{\mathrm{sv}}$ value of $8.59 \times 10^{3} \mathrm{M}^{-1}$ (Figure $2 \mathrm{c}$ ). The $K_{\mathrm{sv}}$ value iscommensurate to some earlier reported MOF-based sensors, such as [La(TPT)(DMSO) $\left.)_{2}\right] \cdot \mathrm{H}_{2} \mathrm{O}\left(1.36 \times 10^{4} \mathrm{M}^{-1}\right)$ [44], [La(TAIP) $(\mathrm{DMF})_{2}$ ] $(\mathrm{DMF})_{0.5}$ $\left(8.86 \times 10^{3} \mathrm{M}^{-1}\right)$ [45], and Eu-MOF-LIC-1 $\left(2.87 \times 10^{4} \mathrm{M}^{-1}\right)$ [46]. The $\mathrm{Fe}^{3+}$ ion detection limit has been calculated as 0.75 and 0.79 ppm for 1 and 2, respectively.

The fluorescence responses of $\mathbf{1}$ and $\mathbf{2}$ towards small molecules were also measured in $N, N$-Dimethylformamide (DMF) suspensions of 1 and 2 [47-49]. The experiments indicated that, among different solvent molecules, nitrobenzene (NB) was having good capacity to decrease the photoluminescent emissions of $\mathbf{1}$ and 2 (Figure $3 \mathrm{a}-\mathrm{c}$ and Figures S6 and S7). Thus, the DMF suspension of both 1 and $\mathbf{2}$ were selected to sense variety of nitro-aromatic compounds (NACs), viz., 2,4,6-trinitrophenol (TNP), 2,4-dinitrotoluene (2,4-DNT), 2,6-dinitrotoluene (2,6-DNT), 2-nitrotoluene(2-NT), 4-nitrotoluene (4-NT), and 1,3-dinitrobenzene (1,3-DNB). The experiments indicated that the increased incorporation of TNP in step-wise manner to the dispersions of $\mathbf{1}$ and $\mathbf{2}$ led to appreciable decrement in fluorescence intensities (Figure 3b,d) [50-55]. However, in comparison to TNP, other NACs, viz., NB, 1,3-DNB, 2,4-DNT, 2,6-DNT, 2-NT and 4-NT, displayedrelatively small quenching effect (Figures S8-S31). The fluorescence quenching efficiencies of both $\mathbf{1}$ and $\mathbf{2}$ were further analyzed using the Stern-Volmer $(\mathrm{S}-\mathrm{V})$ equation, $\left(I_{0} / I\right)=K_{\mathrm{sv}}[\mathrm{Q}]+1$ [22]. From the linear fitting of the S-V plots (Figures S32 and S33), the calculated $K_{\mathrm{sv}}$ value for TNP was found to be $2.85 \times 10^{3} \mathrm{M}^{-1}$ for 
1 and $2.25 \times 10^{3} \mathrm{M}^{-1}$ for $\mathbf{2}$ (Table S1). These $K_{\mathrm{sv}}$ values are almost parallel to those of the previously reported MOF based sensors, such as UIO-67-deppy $\left(2.9 \times 10^{4} \mathrm{M}^{-1}\right)$ [51], [Cd(NDC)0.5(PCA)] $\left(3.5 \times 10^{4} \mathrm{M}^{-1}\right)$ [52], [Tb(1,3,5-BTC)] $\left(3.42 \times 10^{4} \mathrm{M}^{-1}\right)$ [53] and Zn-TCPP $\left(3.59 \times 10^{4} \mathrm{M}^{-1}\right)$ [54]. Based on 38 /slope, the TNP detection limits were 0.86 and $0.94 \mathrm{ppm}$ for $\mathbf{1}$ and $\mathbf{2}$, respectively [56-59]. Hence, the results show that both $\mathbf{1}$ and $\mathbf{2}$ can be utilized to detect nitroaromatics with different electron-withdrawing $-\mathrm{NO}_{2}$ group.
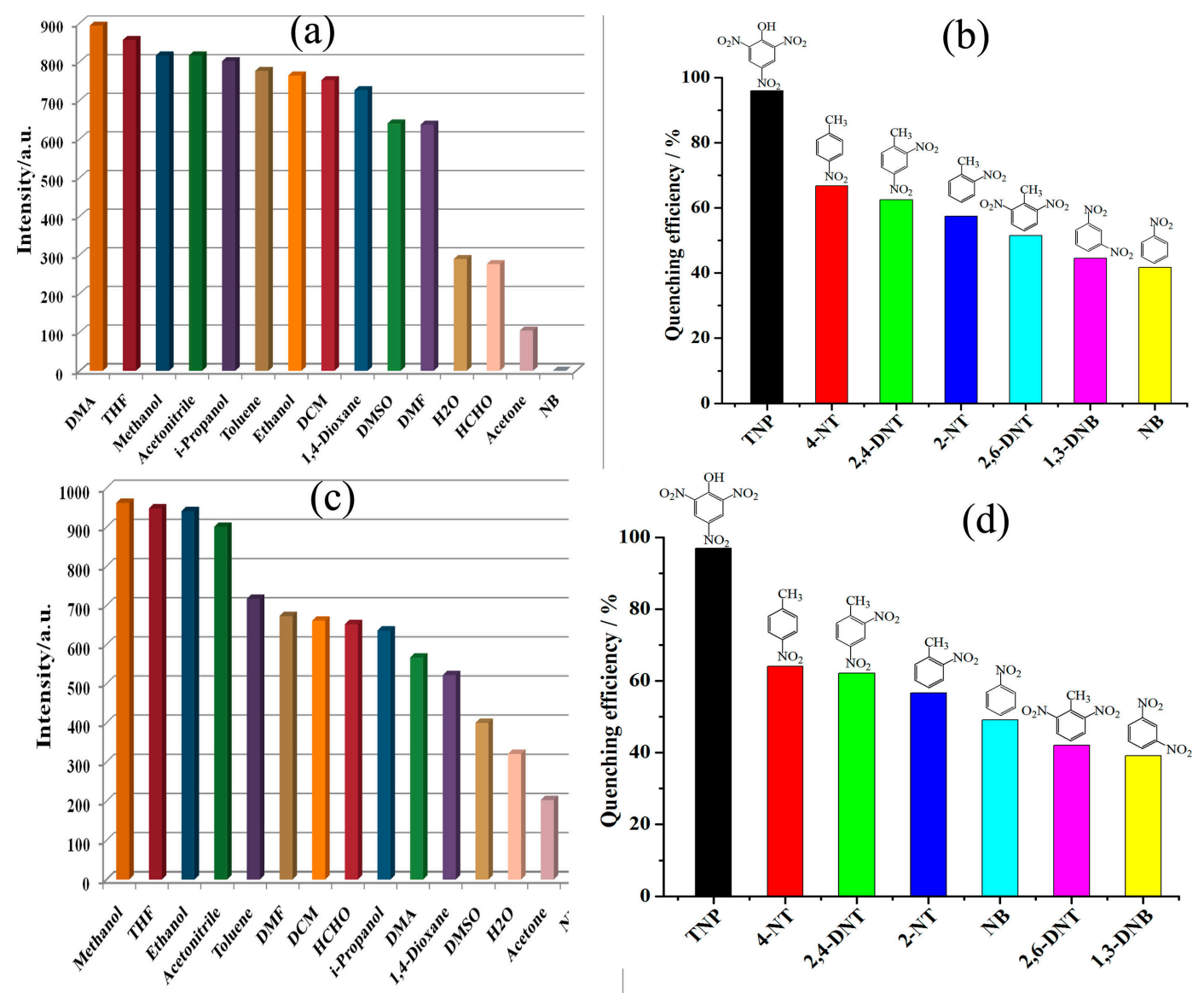

Figure 3. (a,c) The emission intensities of CPs 1 and 2 dispersed in different solvents $\left(\lambda_{\mathrm{ex}}=290 \mathrm{~nm}\right)$; and $(\mathbf{b}, \mathbf{d})$ emissive response spectra of $\mathbf{1}$ and $\mathbf{2}$ for TNP in DMF solutions, respectively.

In addition to experiments, the plausible mechanism associated with the alleviation in fluorescence intensities of $\mathbf{1}$ and $\mathbf{2}$ in presence of different NACs have been addressed with the help of theoretical calculations. The HOMO-LUMO energies of the NACs along with CPs $\mathbf{1}$ and $\mathbf{2}$ were calculated using density functional theory (DFT) at the B3LYP level (Table 1 and Figure S34a,b). The possible reason behind quenching may be the electron transfer operating from the framework of $\mathbf{1}$ or $\mathbf{2}$ to the LUMO of the analytes [5-8,22]. The phenomenon of electron transfer will happen only when the LUMO of the donor MOF 1 or 2 will have higher energy in comparison to LUMO of the acceptor analytes. The LUMO energies of $\mathrm{H}_{4} \mathrm{~L}, \mathbf{1}, \mathbf{2}$ and NACs presented in Table 1 indicate that the LUMOs of all NACs are at comparatively lower energy scale in comparison to $\mathbf{1}$ and $\mathbf{2}$, which facilitates the electron transfer from $\mathbf{1}$ or $\mathbf{2}$ to NACs. However, the observed order of quenching in the emission of $\mathbf{1}$ or $\mathbf{2}$ by these NACs is not in full agreement with the corresponding LUMO energies of NACs, which indicates that the electron transfer phenomenon is not the sole mechanism for the quenching in intensity. Hence, alongwith the electron and energy transfer processes, there may be the possibility of weak interaction operating between CPs and NACs which may also be playing rolein the decrease in 
the emission intensities of both the CPs [60-71]. Additionally, there is also the possibility that there are certain constraints related to transition probability of both the $\mathrm{CPs}$, for instance the NACs inhibits linker motions (at the excited state) in $\mathrm{CPs}$, which might be responsible for the decrement in emission intensity [68-71].

Table 1. The HOMO-LUMO energies (in eV) for different analytes and 1.

\begin{tabular}{ccc}
\hline Ligand/Analyte & HOMO & LUMO \\
\hline 1 & -5.49 & -2.23 \\
2 & -1.89 & -1.55 \\
2-nitrotoluene (2-NT) & -7.28 & -2.32 \\
4-nitrotoluene (4-NT) & -7.36 & -2.32 \\
Nitrobenzene (NB) & -7.60 & -2.43 \\
2,6-dinitrotoluene (2,6-DNT) & -7.91 & -2.87 \\
2,4-dinitrotoluene (2,4-DNT) & -8.11 & -2.98 \\
1,3-dinitrobenzene (1,3-DNB) & -8.42 & -3.14 \\
2,4,6-trinitrophenol (TNP) & -8.54 & -3.55 \\
\hline
\end{tabular}

The UV/Vis absorption spectra for $\mathrm{Fe}\left(\mathrm{NO}_{3}\right)_{3}$ and TNP solutions have been recorded (Figure S35). The electronic absorption spectra of $\mathrm{Fe}^{3+}$ and TNP solution display large overlap with the excitation spectrum of $\mathrm{H}_{4} \mathrm{~L}$. Therefore, the competition absorption of excitation wavelength $(290 \mathrm{~nm})$ energy between $\mathrm{Fe}^{3+}$ aqueous solution and both the CPs may be responsible for the quenching effect.

\subsection{Diffuse-Reflectance UV/Vis Spectroscopy}

To obtain diffuse-reflectance spectra, the UV/Vis spectra for $\mathbf{1}$ and $\mathbf{2}$ were recorded in solid state at RT (room temperature). For both $\mathbf{1}$ and $\mathbf{2}$, the spectra comprise bands in the UV region (Figure S36). The intense absorption band at $\sim 300 \mathrm{~nm}$ may be arising because of the $\pi-\pi^{*}$ transitions of the ligand. In the diffuse reflectance spectroscopy (DRS), the scattered radiation is collected by excluding specularly reflected light which matches closely with the Kubelka-Munk function $F(R)=(1-R)^{2} / 2 R$ [10d]. The energy band gaps $\left(E_{\mathrm{g}}\right)$ which had been calculated by extrapolating the linear region of absorption edge comes equal to 2.83 and $3.03 \mathrm{eV}$ for CPs $\mathbf{1}$ and 2, respectively (Figure S37). These band gap parameters indicate the semiconducting nature of both the CPs (Figure S37). The band gaps of both $\mathbf{1}$ and $\mathbf{2}$ indicate that both may display absorption responses towards UV radiation and concomitantly can have potential to behave as photocatalysts in photodegradation of organic dyes [72-75].

\subsection{Photocatalysis}

The photocatalytic activities of both $\mathbf{1}$ and $\mathbf{2}$ were checked by photo-decomposition of the dyes methyl violet (MV) and rhodamine $\mathrm{B}(\mathrm{RhB})$ in aqueous medium under UV irradiation using a $250 \mathrm{~W}$ Hg lamp. The degradation rates of both the dyes in aqueous medium were checked by observing the change in absorbance of the characteristic absorption bands of both the dyes with time (Figure 4). The non-appearance of any new absorption band in the UV/Vis spectra of dyes indicated their complete decomposition in aqueous medium. The experimental results indicated that the conversion rates of MV and RhB are $83.38 \%$ and $96.15 \%$, respectively, in the presence of CP 1 . To judge whether dyes are degrading under UV irradiation even in absence of $\mathrm{CPs}$, the catalytic degradation efficiency of the control experiment (in the absence of CP 1) was carried out for 100 min (Figures S38 and S39). During this period, in the absence of $\mathbf{1}$, the degradation percentages of $\mathrm{MV}$ and $\mathrm{RhB}$ were $28.02 \%$ and $52.07 \%$, respectively. These results validate that the presence of $\mathbf{1}$ is crucial to photo-degrade MV and $\mathrm{RhB}$. In addition, the photo-decomposition of $\mathrm{RhB}$ was more in comparison to $\mathrm{MV}$ in presence of $\mathbf{1}$ under similar reaction conditions. The mechanism related to the photo-degradation of $\mathrm{MV}$ and $\mathrm{RhB}$ can be substantiated by the fact that UV irradiation of CPs $\frac{1}{2}$ induces excited photo-electron to moves from thevalence band (VB) to the conduction band (CB). The electron deficient holes generated in 
VB of CPs at $\mathrm{Cd}$ (II) sites generates hydroxyl radicals alongwith other oxidants which decomposes the organic dyes [76-83]. After photocatalysis, CPs $\mathbf{1}$ and $\mathbf{2}$ were filtered off and observed under an optical microscope. The unchanged Powder X-ray Powder Diffracter (PXRD) patterns for both 1 and $\mathbf{2}$ indicates that both the CPs remains stable after photo-degrading MV/Rh B. In addition, the diffractogram identity for the sample before and after the photocatalytic experiment would not exclude a partial dissolution or decomposition of the material [78] (Figure S40).

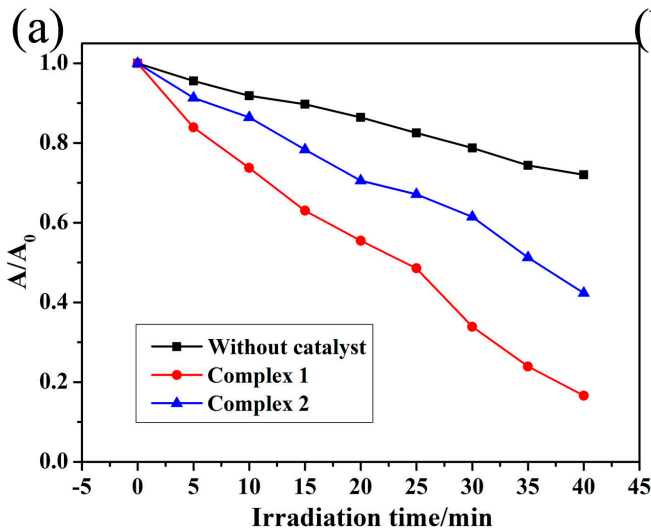

(b)

(c)
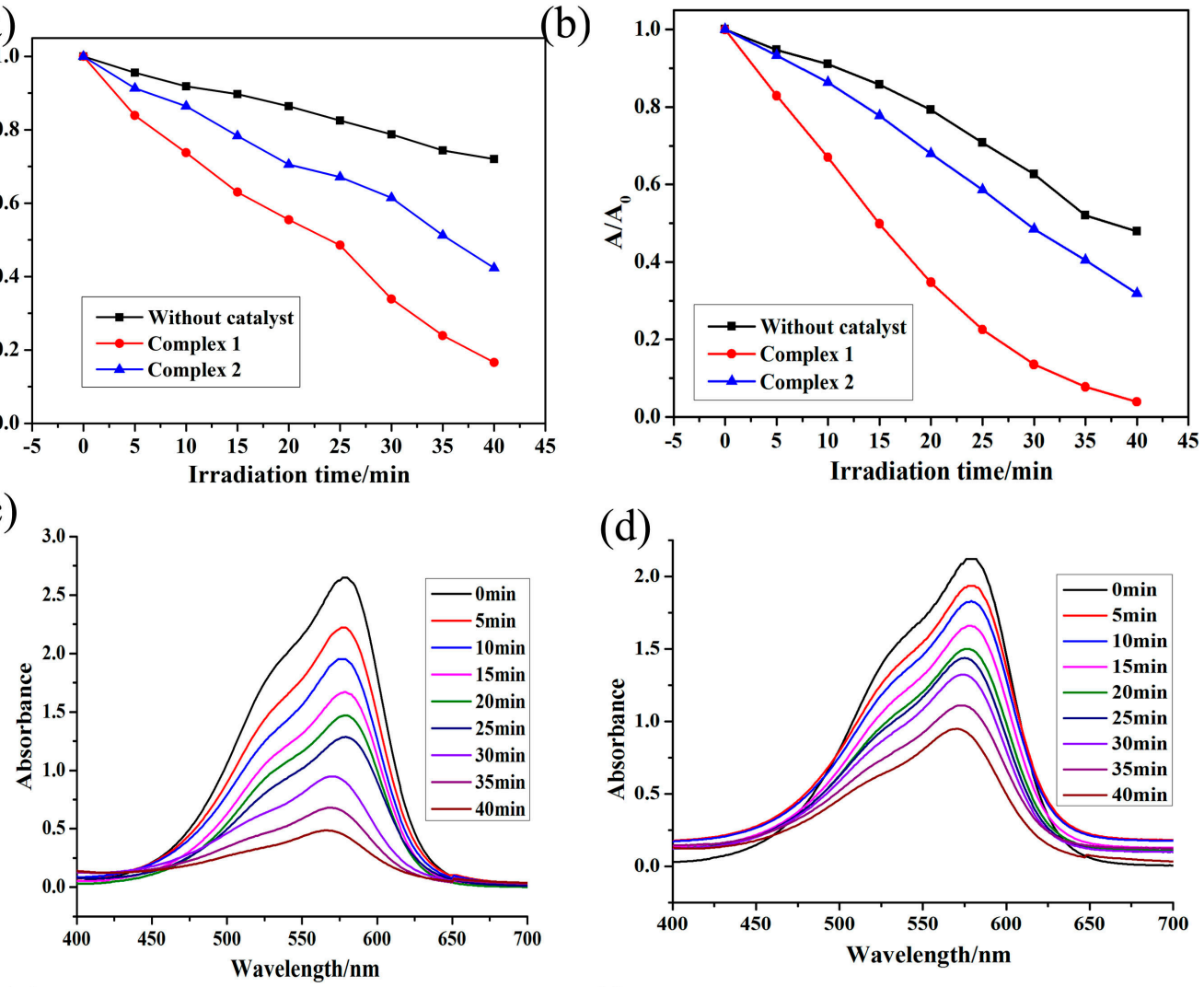

(e)
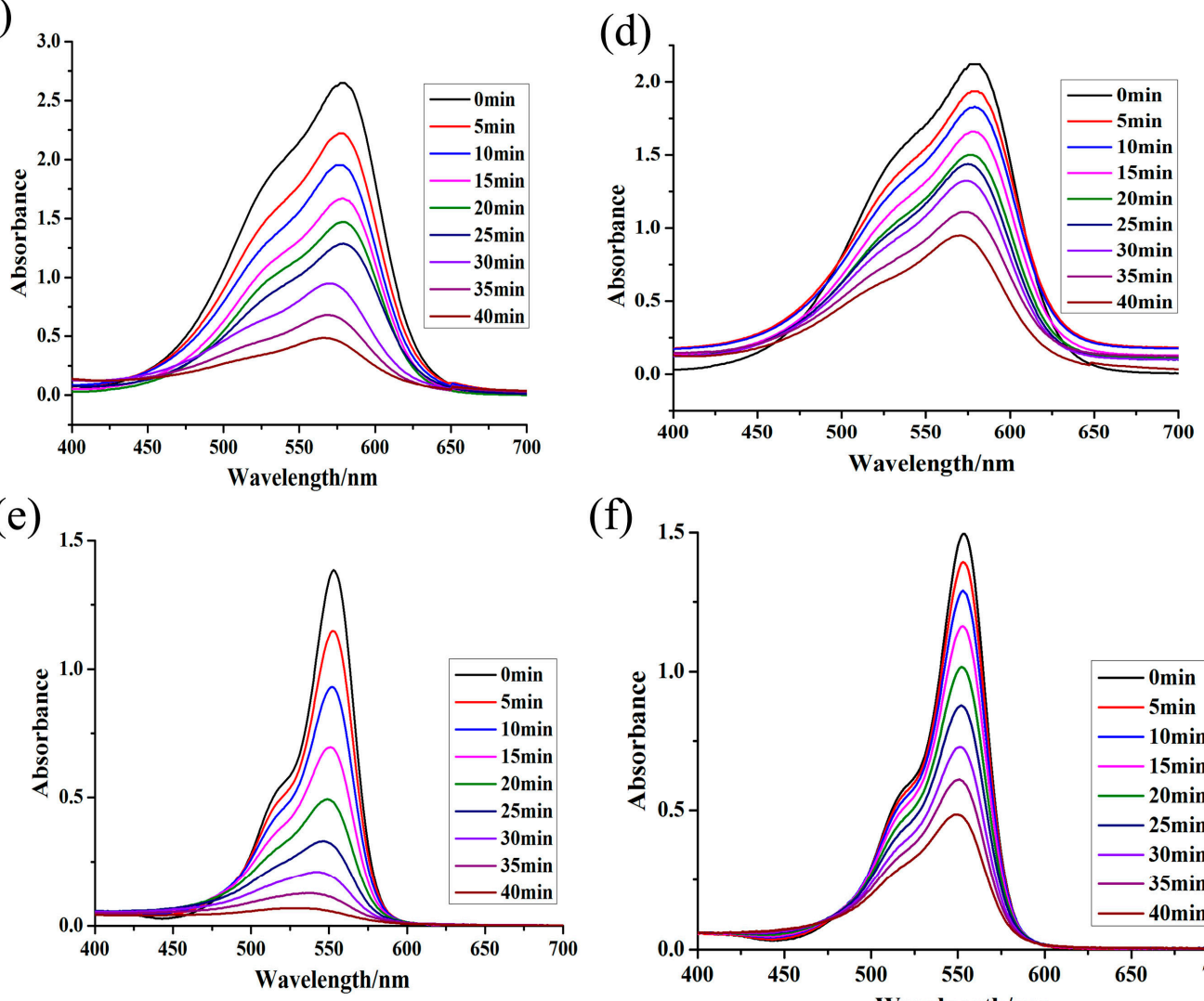

(f)

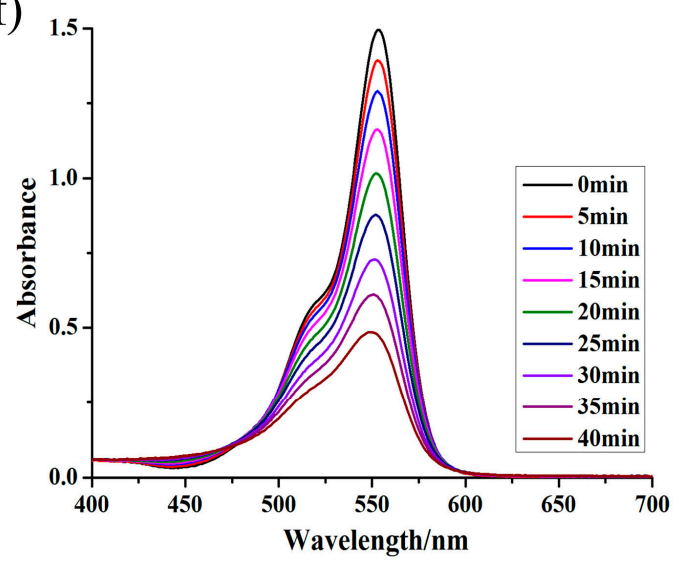

Figure 4. (a,b) The plot displaying photocatalytic degradation kinetics of MV and RhB in presence ofof CPs 1 and 2; and (c-f) UV-vis absorption spectra of the MV and RhB solution during the decomposition reaction under $250 \mathrm{~W} \mathrm{Hg}$ lamp irradiation in the presence of CPs $\mathbf{1}$ and 2, respectively.

Although the band gap of $\mathbf{2}$ is adjacent to that of $\mathbf{1}$, their photocatalytic performances are distinctively different, which could be influenced by the differences in the CP frameworks $[29,30]$, because of the small difference in the optical band gap between each group of $\mathrm{CP}\left(\Delta E_{\mathrm{g}} \leq 0.12 \mathrm{eV}\right)$. 
Its degradation rate is the smallest, only $15.1 \%$ for RhB in 2 . Herein, we tentatively surmise that it is possibly caused by the special structure of 2 . As described above, complex $\mathbf{2}$ is $2 \mathrm{D}$ ladder like layer, the dense structure of which will be not conducive to the adsorption and desorption of $\mathrm{O}_{2} /$ hydroxyl $\left(\mathrm{OH}^{-}\right)$on its surface and the transport of excited holes/electrons to its surface, to retard the formation of the hydroxyl radicals $(\cdot \mathrm{OH})$ and further impede the occurrence of the catalytic to retard the formation of the hydroxyl radicals $(\cdot \mathrm{OH})$ and further impede the occurrence of the catalytic reaction.

The probable photo-decomposition mechanism of organic dyes in presence of $\mathbf{1}$ and $\mathbf{2}$ have been addressed by band structure calculations using density functional theory method. As evident in Figure 5, the valence band which is lying just beneath the Fermi level in $\mathbf{1}$ is having contributions from aromatic carbon centers and oxygen centers with small contribution by the $\mathrm{Cd}(\mathrm{II})$ and nitrogen centers. Likewise, in 2, the main contribution for the valence band coming from aromatic carbon centers, nitrogen and oxygen centers with negligible contribution by the $\mathrm{Cd}$ (II) centers. In both $\mathbf{1}$ and 2 , the conduction band lying just above the Fermi level in the range of -2.50 to $-1.86 \mathrm{eV}$ is derived from aromatic carbons, nitrogen and oxygen. Therefore, the electronic transition in $\mathbf{1}$ mainly takes place from the $\mathrm{Cd}(\mathrm{II})$ center, nitrogen, oxygen and aromatic region, but in $\mathbf{2}$ this electronic transition is operating from nitrogen, oxygen and aromatic region while the contribution from $\mathrm{Cd}(\mathrm{II})$ is negligible. This non-involvement of Cd(II) center in electronic transition may be the possible reason for the relatively poor photocatalytic property of $\mathbf{2}$ in comparison to 1 . In a typical photocatalytic process, the samples can be excited to produce electron-hole pairs under visible light irradiation and as band structure calculations reveal that hole moves to metal centers and the electron migrates to aromatic entity. The generation of holes on the $\mathrm{d}^{10}$-centers will correspond to its oxidation which is can now oxidize the dye to reduce back to $\mathrm{d}^{10}$ configuration again [22].

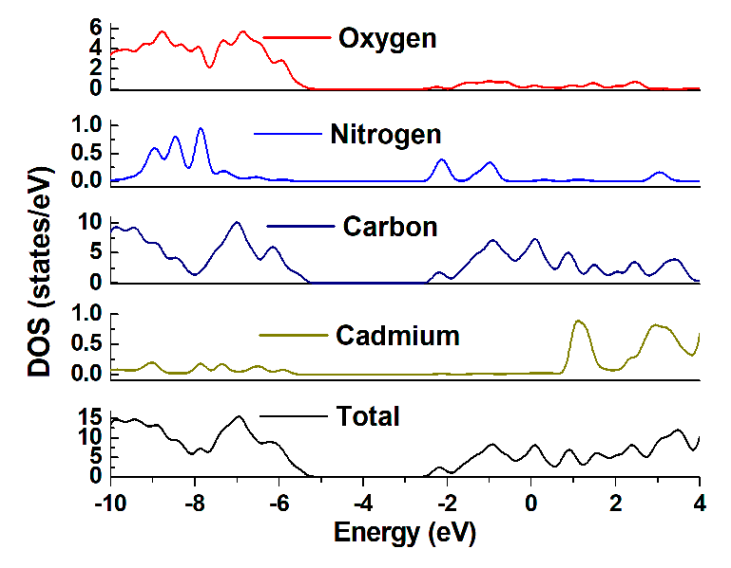

1

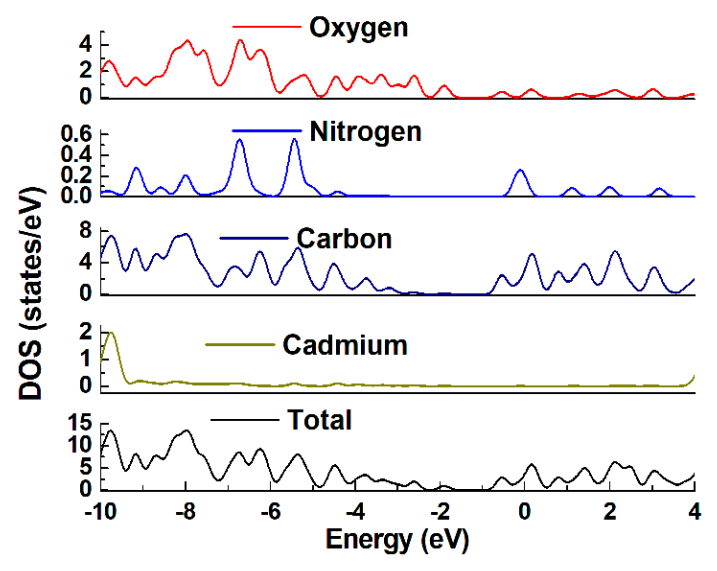

2

Figure 5. The DOS and partial DOS plots for CPs 1 and 2.

\section{Conclusions}

In conclusion, the fluorescent CPs 1 and 2 reported herein offered selective sensing property against nitro-aromatics, especially against TNP. Additionally, they can also be used as a photocatalyst for photo-decomposition of aromatic dyes. The quantum chemical calculations prove the existence of both electron and energy transfer processes, in addition to electrostatic interaction between the CPs $\mathbf{1}$ and $\mathbf{2}$ and nitro-aromatics, which may be responsible for the unprecedented selective fluorescence quenching. In addition, the density of states calculations revealed that inferior catalytic properties in 2 may arise because of the poor involvement of $\mathrm{Cd}$ (II) center in photoexcitation. Hence, the presented investigation proves that not only the choice of polycarboxylates ligand but also the selection of appropriate polypyridyl moiety in the fabrication of CPs plays a crucial role in the development of 2D framework. In addition, by suitable selection of both polycarboxylate linker as well as polypyridyl 
spacer, one can develop appropriate CPs that can behave as potential sensors and photocatalyst. The presented work will induce stimulus to develop similar CPs for the selective and sensitive detection of nitro-aromatics as well as to synthesize new photocatalysts for organic dye degradation.

Supplementary Materials: The following are available online at www.mdpi.com/2073-4360/10/3/274/s1.

Acknowledgments: The authors acknowledge financial assistance from Sichuan University of Science and Engineering (Nos. 2015RC26, 2015RC29 and 2017RCL02); National Science Fund of China (No. 21701033); the Education Committee of Sichuan Province (No. 17ZA0264); the Project of Zigong Science \& Technology (No. 2016HG05); the Opening Project of Key Laboratory of Green Chemistry of Sichuan Institutes of Higher Education (No. LZJ1705); and Council of Scientific and Industrial Research, New Delhi (No. 01(2899)/17/EMR-II).

Conflicts of Interest: The authors declare no competing conflict of interest.

\section{References}

1. Xie, Z.G.; Ma, L.Q.; deKrafft, K.E.; Jin, A.; Lin, W.B. Porous phosphorescent coordination polymers for oxygen sensing. J. Am. Chem. Soc. 2010, 132, 922-923. [CrossRef] [PubMed]

2. Chen, B.; Yang, Y.; Zapata, F.; Lin, G.; Qian, G.; Lobkovsky, E.B. Luminescent open metal sites within a metal-organic framework for sensing small molecules. Adv. Mater. 2007, 19, 1693-1696. [CrossRef]

3. Bauer, C.A.; Timofeeva, T.V.; Settersten, T.B.; Patterson, B.D.; Liu, V.H.; Simmons, B.A.; Allendrof, M.D. Influence of connectivity and porosity on ligand-based luminescence in zinc metal-organic frameworks. J. Am. Chem. Soc. 2007, 129, 7136-7144. [CrossRef] [PubMed]

4. Chen, B.L.; Wang, L.B.; Zapata, F.; Qian, G.D.; Lobkovsky, E.B. A luminescent microporous metal-organic framework for the recognition and sensing of anions. J. Am. Chem. Soc. 2008, 130, 6718-6719. [CrossRef] [PubMed]

5. Chen, Y.; Li, Z.Y.; Liu, Q.; Shen, Y.C.; Wu, X.Z.; Xu, D.D.; Ma, X.L.; Wang, L.H.; Chen, Q.H.; Zhang, Z.J.; et al. Microporous metal-organic framework with lantern-like dodecanuclear metal coordination cages as nodes for selective adsorption of $C_{2} / C_{1}$ mixtures and sensing of nitrobenzene. Cryst. Growth Des. 2015, 15, 3847-3852. [CrossRef]

6. Liu, J.Q.; Wu, J.; Li, F.M.; Liu, W.C.; Li, B.H.; Wang, J.; Li, Q.L.; Yadav, R.; Kumar, A. Luminescent sensing from a new Zn (II) metal-organic framework. RSC Adv. 2016, 6, 31161-31166. [CrossRef]

7. Wang, J.; Wu, X.R.; Liu, J.Q.; Li, B.H.; Singh, A.; Kumar, A.; Batten, S.R. An uncommon (5,5)-connected 3D metal organic material for selective and sensitive sensing of nitroaromatics and ferric ion: experimental studies and theoretical analysis. CrystEngComm 2017, 19, 3519-3525. [CrossRef]

8. Lu, L.; Wu, J.; Wang, J.; Liu, J.Q.; Li, B.H.; Singh, A.; Kumar, A.; Batten, S.R. An uncommon 3D 3,3,4,8-c Cd (II) metal-organic framework for highly efficient luminescent sensing and organic dye adsorption: experimental and theoretical insight. CrystEngComm 2017, 19, 7057-7067. [CrossRef]

9. Liu, J.Q.; Wang, W.J.; Luo, Z.D.; Li, B.H.; Yuan, D.Q. Microporous metal-organic framework based on ligand-truncation strategy with high performance for gas adsorption and separation. Inorg. Chem. 2017, 56, 10215-10219. [CrossRef] [PubMed]

10. Liang, Y.T.; Yang, G.P.; Liu, B.; Yan, Y.T.; Xi, Z.P.; Wang, Y.Y. Four super water-stable lanthanide-organic frameworks with active uncoordinated carboxylic and pyridyl groups for selective luminescence sensing of $\mathrm{Fe}^{3+}$. Dalton Trans. 2015, 44, 13325-13330. [CrossRef] [PubMed]

11. Jin, J.C.; Pang, L.Y.; Yang, G.P.; Hou, L.; Wang, Y.Y. Two porous luminescent metal-organic frameworks: quantifiable evaluation of dynamic and static luminescent sensing mechanisms towards $\mathrm{Fe}^{3+}$. Dalton Trans. 2015, 44, 17222-17228. [CrossRef] [PubMed]

12. Carter, K.P.; Young, A.M.; Palmer, A.E. Fluorescent sensors for measuring metal ions in living systems. Chem. Rev. 2014, 114, 4564-4601. [CrossRef] [PubMed]

13. Sahoo, S.K.; Sharma, D.; Bera, R.K.; Crisponic, G.; Callan, J.F. Iron (III) selective molecular and supramolecular fluorescent probes. Chem. Soc. Rev. 2012, 41, 7195-7227. [CrossRef] [PubMed]

14. Jin, J.C.; Wu, J.; He, Y.X.; Li, B.H.; Liu, J.Q.; Prasad, R.; Kumar, A.; Batten, S.R. A 3D luminescent Zn (II) MOF for the detection of high explosives and the degradation of organic dyes: an experimental and computational study. CrystEngComm 2017, 19, 6464-6472. [CrossRef] 
15. Liu, J.Q.; Wu, J.; Luo, Z.D.; Li, B.H.; Singh, A.; Kumar, A. A porous zinc(II) metal-organic framework exhibiting high sensing ability for ferric and nitroaromatics as well as photocatalytic degradation activities against organic dyes. J. Coord. Chem. 2017, 70, 3946-3958. [CrossRef]

16. Dau, P.V.; Cohen, S.M. Cyclometalated metal-organic frameworks as stable and reusable heterogeneous catalysts for allylic $N$-alkylation of amines. Chem. Commun. 2013, 49, 6128-6130. [CrossRef] [PubMed]

17. Dau, P.V.; Cohen, S.M. The influence of nitro groups on the topology and gas sorption property of extended Zn (II)-paddlewheel MOFs. CrystEngComm 2013, 15, 9304-9307. [CrossRef]

18. Zhang, T.; Lin, W. Metal-organic frameworks for artificial photosynthesis and photocatalysis. Chem. Soc. Rev. 2014, 43, 5982-5993. [CrossRef] [PubMed]

19. Sun, F.; Yin, Z.; Wang, Q.Q.; Sun, D.; Zeng, M.H.; Kurmoo, M. Tandem postsynthetic modification of a metal-organic framework by thermal elimination and subsequent bromination: Effects on absorption properties and photoluminescence. Angew. Chem. Int. Ed. 2013, 52, 4636-4641. [CrossRef]

20. Wang, X.X.; Wang, X.Q.; Niu, X.Y.; Hu, T.P. Three novel metal-organic frameworks based on an unsymmetrical rigid carboxylate ligand for luminescence sensing of nitrobenzene derivatives and magnetic properties. CrystEngComm 2016, 18, 7471-7477. [CrossRef]

21. Cui, Y.; Xu, H.; Yue, Y.; Guo, Z.; Yu, J.; Chen, Z.; Gao, J.; Yang, Y.; Qian, G.; Chen, B. A luminescent mixed-lanthanide metal-organic framework thermometer. J. Am. Chem. Soc. 2012, 134, 3979-3982. [CrossRef] [PubMed]

22. Dau, P.V.; Kim, M.; Cohen, S.M. Site-selective cyclometalation of a metal-organic framework. Chem. Sci. 2013, 4, 601-605. [CrossRef]

23. Liu, X.P.; Xiao, Z.Y.; Xu, J.; Xu, W.B.; Sang, P.P.; Zhao, L.M.; Zhu, H.Y.; Sun, D.F.; Guo, W.Y. A NbO-type copper metal-organic framework decorated with carboxylate groups exhibiting highly selective $\mathrm{CO}_{2}$ adsorption and separation of organic dyes. J. Mater. Chem. A 2016, 4, 13844-13851. [CrossRef]

24. Li, B.H.; Wu, J.; Liu, J.Q.; Gu, C.Y.; Xu, J.W.; Luo, M.M.; Yadav, R.; Kumar, A.; Batten, S.R. A luminescent Zinc (II) metal-organic framework for selective detection of nitroaromatics, $\mathrm{Fe}^{3+}$ and $\mathrm{CrO}_{4}{ }^{2-}: \mathrm{A}_{\text {versatile }}$ threefold fluorescent sensor. ChemPlusChem 2016, 81, 885-892. [CrossRef]

25. Liu, J.Q.; Li, G.P.; Liu, W.C.; Li, Q.L.; Li, B.H.; Gable, R.W.; Batten, S.R. Two unusual nanocage-based Ln-MOFs with triazole sites: Highly fluorescent sensing for $\mathrm{Fe}^{3+}$ and $\mathrm{Cr}_{2} \mathrm{O}_{7}{ }^{2-}$, and selective $\mathrm{CO}_{2}$ capture. ChemPlusChem 2016, 81, 1299-1304. [CrossRef]

26. Hou, G.G.; Liu, Y.; Liu, Q.K.; Ma, J.P.; Dong, Y.B. NbO lattice MOFs based on octahedral M (II) and ditopic pyridyl substituted diketonate ligands: Structure, encapsulation and guest-driven luminescent property. Chem. Commun. 2011, 47, 10731-10733. [CrossRef] [PubMed]

27. Hao, J.N.; Yan, B. Amino-decorated lanthanide (III) organic extended frameworks for multi-color luminescence and fluorescence sensing. J. Mater. Chem. C. 2014, 2, 6758-6764. [CrossRef]

28. D'Alessandro, D.M.; Kanga, J.R.R.; Caddy, J.S. Towards conducting metal-organic frameworks. Aust. J. Chem. 2011, 64, 718-722. [CrossRef]

29. Silva, C.G.; Corma, A.; García, H. Metal-organic frameworks as semiconductors. J. Mater. Chem. 2010, 20, 3141-3156. [CrossRef]

30. So, M.C.; Wiederrecht, G.P.; Mondloch, J.E.; Hupp, J.T.; Farha, O.K. Metal-organic framework materials for light-harvesting and energy transfer. Chem. Commun. 2015, 51, 3501-3510. [CrossRef] [PubMed]

31. Jin, J.C.; Wu, J.; Liu, W.C.; Ma, A.Q.; Liu, J.Q.; Singh, A.; Kumar, A. A new Zn(II) metal-organic framework having $3 \mathrm{D} \mathrm{CdSO}_{4}$ topology as luminescent sensor and photocatalyst for degradation of organic dyes. New J. Chem. 2018, 42, 2767-2775. [CrossRef]

32. Khan, N.A.; Hasan, Z.; Jhung, S.H. Adsorptive removal of hazardous materials using metal-organic frameworks (MOFs): A review. J. Hazard. Mater. 2013, 244-245, 444-456. [CrossRef] [PubMed]

33. Xuan, W.; Zhu, C.; Liu, Y.; Cui, Y. Mesoporous metal-organic framework materials. Chem. Soc. Rev. 2012, 41, 1677-1695. [CrossRef] [PubMed]

34. Song, L.; Zhang, J.; Sun, L.; Xu, F.; Li, F.; Zhang, H.; Si, X.; Jiao, C.; Li, Z.; Liu, S.; et al. Mesoporous metal-organic frameworks: Design and applications. Energy Environ. Sci. 2012, 5, 7508-7520. [CrossRef]

35. Lan, Y.Q.; Jiang, H.L.; Li, S.L.; Xu, Q. Mesoporous metal-organic frameworks with size-tunable cages: Selective $\mathrm{CO}_{2}$ uptake, encapsulation of $\mathrm{Ln}^{3+}$ cations for luminescence, and column-chromatographic dye separation. Adv. Mater. 2011, 23, 5015-5020. [CrossRef] [PubMed] 
36. Sheldrick, G.M. SHELXT - Integrated space-group and crystal-structure determination. Acta Crystallogr. Sect. A Found. Adv. 2015, A71, 3-8. [CrossRef] [PubMed]

37. Becke, A.D. Density-functional thermochemistry. III. The role of exact exchange. J. Chem. Phys. 1993, 98, 5648-5652. [CrossRef]

38. Lee, C.T.; Yang, W.T.; Parr, R.G. Development of the Colle-Salvetti correlation-energy formula into a functional of the electron density. Phys. Rev. B 1998, 37, 785-789. [CrossRef]

39. Frisch, M.J.; Trucks, G.W.; Schlegel, H.B.; Scuseria, G.E.; Robb, M.A.; Cheeseman, J.R.; Montgomery, J.A.; Vreven, T., Jr.; Kudin, K.N.; Burant, J.C.; et al. GAUSSIAN09; Gaussian, Inc.: Wallingford, CT, USA, 2009.

40. O'Boyle, N.M.; Tenderholt, A.L.; Langner, K.M. Cclib: A library for package-independent computational chemistry algorithms. J. Comput. Chem. 2008, 29, 839-845. [CrossRef] [PubMed]

41. Fan, Y.; Si, C.D.; Hou, C.; Yao, X.Q.; Hu, D.C.; Yang, Y.X.; Liu, J.C. Three complexes of manganese (II) based on a new semirigid tetracarboxylate and $N$-containing ligands: Synthesis, crystal structures and magnetic properties. Polyhedron 2015, 98, 64-70. [CrossRef]

42. Allendorf, M.D.; Bauer, C.A.; Bhakta, R.K.; Houk, R.J.T. Luminescent metal-organic frameworks. Chem. Soc. Rev. 2009, 38, 1330-1352. [CrossRef] [PubMed]

43. Stavila, V.; Talin, A.A.; Allendorf, M.D. MOF-based electronic and opto-electronic devices. Chem. Soc. Rev. 2014, 43, 5994-6010. [CrossRef] [PubMed]

44. Zhang, C.Q.; Yan, Y.; Pan, Q.H.; Sun, L.B.; He, H.M.; Liu, Y.L.; Liang, Y.Z.Q.; Li, J.Y. A microporous lanthanum metal-organic framework as a bi-functional chemosensor for the detection of picric acid and $\mathrm{Fe}^{3+}$ ions. Dalton Trans. 2015, 44, 13340-13346. [CrossRef] [PubMed]

45. Wang, D.; Sun, L.B.; Hao, L.C.Q.; Yan, Y.; Liang, Z.Q. Lanthanide metal-organic frameworks based on a 1,2,3-triazole-containing tricarboxylic acid ligand for luminescence sensing of metal ions and nitroaromatic compounds. RSC Adv. 2016, 6, 57828-57834. [CrossRef]

46. Singh, A.; Raj, T.; Aree, T.; Singh, N. Fluorescent organic nanoparticles of biginelli-based molecules: recognition of $\mathrm{Hg}^{2+}$ and $\mathrm{Cl}^{-}$in an aqueous medium. Inorg. Chem. 2013, 52, 13830-13832. [CrossRef] [PubMed]

47. Chen, J.L.; Yi, F.Y.; Yu, H.; Jiao, S.H.; Pang, G.S.; Sun, Z.M. Fast response and highly selective sensing of amine vapors using a luminescent coordination polymer. Chem. Commun. 2014, 50, 10506-10509. [CrossRef] [PubMed]

48. Lan, A.; Li, K.; Wu, H.; Olson, D.H.; Emge, T.J.; Ki, W.; Hong, M.; Li, J. A luminescent microporous metal-organic framework for the fast and reversible detection of high explosives. Angew. Chem. Int. Ed. 2009, 48, 2334-2338. [CrossRef] [PubMed]

49. Zhang, M.; Feng, G.; Song, Z.; Zhou, Y.P.; Chao, H.Y.; Yuan, D.; Tan, T.T.Y.; Guo, Z.; Hu, Z.; Tang, B.Z.; et al. Two-dimensional metal-organic framework with wide channels and responsive turn-on fluorescence for the chemical sensing of volatile organic compounds. J. Am. Chem. Soc. 2014, 136, 7241-7244. [CrossRef] [PubMed]

50. Zhu, X.D.; Li, Y.; Zhou, W.X.; Liu, R.M.; Ding, Y.J.; Lü, J.; Proserpiocd, D.M. Metal-organic frameworks assembled from flexible alicyclic carboxylate and bipyridyl ligands for sensing of nitroaromatic explosives. CrystEngComm 2016, 18, 4530-4537. [CrossRef]

51. Nagarkar, S.S.; Desai, A.V.; Ghosh, S.K. A fluorescent metal-organic framework for highly selective detection of nitro explosives in the aqueous phase. Chem. Commun. 2014, 50, 8915-8918. [CrossRef] [PubMed]

52. Nagarkar, S.S.; Joarder, B.; Chaudhari, A.K.; Mukherjee, S.; Ghosh, S.K. Highly selective detection of nitro explosives by a luminescent metal-organic framework. Angew. Chem. Int. Ed. 2013, 52, 2881-2885. [CrossRef] [PubMed]

53. Xiao, J.D.; Qiu, L.G.; Ke, F.; Yuan, Y.P.; Xu, G.S.; Wang, Y.M.; Jiang, X. Rapid synthesis of nanoscale terbium-based metal-organic frameworks by a combined ultrasound-vapour phase diffusion method for highly selective sensing of picric acid. J. Mater. Chem. A 2013, 1, 8745-8752. [CrossRef]

54. Jiang, Y.Y.; Sun, L.B.; Du, J.F.; Liu, Y.C.; Shi, H.Z.; Liang, Z.Q.; Li, J.Y. Multifunctional zinc metal-organic framework based on designed $\mathrm{H}_{4} \mathrm{TCPP}$ ligand with aggregation-induced emission effect: $\mathrm{CO}_{2}$ adsorption, luminescence, and sensing property. Cryst. Growth Des. 2017, 17, 2090-2096. [CrossRef]

55. Zhou, Y.; Chen, H.H.; Yan, B. An $\mathrm{Eu}^{3+}$ post-functionalized nanosized metal-organic framework for cation exchange-based $\mathrm{Fe}^{3+}$-sensing in an aqueous environment. J. Mater. Chem. A 2014, 2, 13691-132697. [CrossRef] 
56. Yang, C.X.; Ren, H.B.; Yan, X.P. Fluorescent metal-organic framework MIL-53(Al) for highly selective and sensitive detection of $\mathrm{Fe}^{3+}$ in aqueous solution. Anal. Chem. 2013, 85, 7441-7446. [CrossRef] [PubMed]

57. Xiang, S.; Zhou, W.; Zhang, Z.; Green, M.A.; Liu, Y.; Chen, B. Open metal sites within isostructural metal-organic frameworks for differential recognition of acetylene and extraordinarily high acetylene storage capacity at room temperature. Angew. Chem. Int. Ed. 2010, 49, 4615-4618. [CrossRef] [PubMed]

58. Wang, J.; Li, Y.; Jiang, M.; Liu, Y.H.; Zhang, L.W.; Wu, P.Y. A highly chemically stable metal-organic framework as a luminescent probe for the regenerable ratiometric sensing of pH. Chem. Eur. J. 2016, 22, 13023-13027. [CrossRef] [PubMed]

59. Tang, Q.; Liu, S.X.; Liu, Y.W.; Miao, J.; Li, S.J.; Zhang, L.; Shi, Z.; Zheng, Z.P. Cation sensing by a luminescent metal-organic framework with multiple Lewis basic sites. Inorg. Chem. 2013, 52, 2799-2801. [CrossRef] [PubMed]

60. Li, Q.W.; Liu, J.L.; Jia, J.H.; Leng, J.D.; Lin, W.Q.; Chen, Y.C.; Tong, M.L. Fluorescent single-ion magnets: molecular hybrid $\left(\mathrm{HNEt}_{3}\right)\left[\mathrm{Dy}_{\mathrm{x}} \mathrm{Yb}_{1-\mathrm{x}}(\mathrm{bpyda})_{2}\right](\mathrm{x}=0.135-1)$. Dalton Trans. 2013, 42, 11262-11270. [CrossRef] [PubMed]

61. Chen, B.L.; Eddaoudi, M.; Hyde, S.T.; O'Keeffe, M.; Yaghi, O.M. Interwoven metal-organic framework on a periodic minimal surface with extra-large pores. Science 2001, 291, 1021-1023. [CrossRef] [PubMed]

62. Hou, Y.L.; Xu, H.; Cheng, R.R.; Zhao, B. Controlled lanthanide-organic framework nanospheres as reversible and sensitive luminescent sensors for practical applications. Chem. Commun. 2015, 51, 6769-6772. [CrossRef] [PubMed]

63. Jin, J.C.; Wu, X.R.; Luo, Z.D.; Deng, F.Y.; Liu, J.Q.; Singh, A.; Kumar, A. Luminescent sensing and photocatalytic degradation properties of an uncommon (4,5,5)-connected 3D MOF based on 3,5-Di(3',5'-dicarboxylphenyl)benzoic acid. CrystEngComm 2017, 19, 4368-4377. [CrossRef]

64. Pramanik, S.; Zheng, C.; Zhang, X.; Emge, T.J.; Li, J. New microporous metal-organic framework demonstrating unique selectivity for detection of high explosives and aromatic compounds. J. Am. Chem. Soc. 2011, 133, 4153-4155. [CrossRef] [PubMed]

65. Zhang, Z.; Xiang, S.; Rao, X.; Zheng, Q.; Fronczek, F.R.; Qian, G.; Chen, B. A rod packing microporous metal-organic framework with open metal sites for selective guest sorption and sensing of nitrobenzene. Chem. Commun. 2010, 46, 7205-7207. [CrossRef] [PubMed]

66. Zhang, C.; Che, Y.; Zhang, Z.; Yang, X.; Zang, L. Fluorescent nanoscale zinc (II)-carboxylate coordination polymers for explosive sensing. Chem. Commun. 2011, 47, 2336-2338. [CrossRef] [PubMed]

67. Kreno, L.E.; Leong, K.; Farha, O.K.; Allendorf, M.; Van Duyne, R.P.; Hupp, J.T. Metal-organic framework materials as chemical sensors. Chem. Rev. 2012, 112, 1105-1125. [CrossRef] [PubMed]

68. Lin, R.B.; Liu, S.Y.; Ye, J.W.; Li, X.Y.; Zhang, J.P. Photoluminescent metal-organic frameworks for gas sensing. Adv. Sci. 2016, 3, 1500434. [CrossRef] [PubMed]

69. Li, J.; Yang, G.P.; Hou, L.; Cui, L.; Li, Y.P.; Wang, Y.Y.; Shi, Q.Z. Three new solvent-directed 3D lead (II)-MOFs displaying the unique properties of luminescence and selective $\mathrm{CO}_{2}$ sorption. Dalton Trans. 2013, 42, 13590-13598. [CrossRef] [PubMed]

70. Yang, Y.J.; Wang, M.J.; Zhang, K.L. A novel photoluminescent Cd(II)-organic framework exhibiting rapid and efficient multi-responsive fluorescence sensing for trace amounts of $\mathrm{Fe}^{3+}$ ions and some NACs, especially for 4-nitroaniline and 2-methyl-4-nitroaniline. J. Mater. Chem. C. 2016, 4, 11404-11418. [CrossRef]

71. Zhao, S.; Lv, X.X.; Shi, L.L.; Li, B.L.; Wu, B. An unusual (4,4)-connected 3D porous cadmium metal-organic framework as a luminescent sensor for detection of nitrobenzene. RSC Adv. 2016, 6, 56035-56041. [CrossRef]

72. Zhao, S.; Ding, J.G.; Zheng, T.R.; Li, K.; Li, B.L.; Wu, B. The 3D and 2D cadmium coordination polymers as luminescent sensors for detection of nitroaromatics. J. Lumin. 2017, 188, 356-364. [CrossRef]

73. Sun, Q.; Lu, J.; Li, J.L.; Jiang, L.; Gu, W.; Liu, X.; Tian, J.L.; Yan, S.P. Synthesis, crystal structures, DNA binding and cleavage properties and protein binding activities of three mononuclear cobalt (II) complexes. Appl. Organomet. Chem. 2014, 28, 259-266. [CrossRef]

74. Li, D.X.; Ni, C.Y.; Chen, M.M.; Dai, M.; Zhang, W.H.; Yan, W.Y.; Qi, H.X.; Ren, Z.G.; Lang, J.P. Construction of $\mathrm{Cd}$ (II) coordination polymers used as catalysts for the photodegradation of organic dyes in polluted water. CrystEngComm 2014, 16, 2158-2167. [CrossRef] 
75. Liu, L.; Ding, J.; Li, M.; Lv, X.F.; Wu, J.; Hou, H.W.; Fan, Y.T. Structural variability, topological analysis and photocatalytic properties of neoteric $\mathrm{Cd}(\mathrm{II})$ coordination polymers based on semirigid bis(thiazolylbenzimidazole) and different types of carboxylic acid linkers. Dalton Trans. 2014, 43, 12790-12799. [CrossRef] [PubMed]

76. Liu, B.; Yu, Z.T.; Yang, J.; Wu, H.; Liu, Y.Y.; Ma, J.F. First three-dimensional inorganic-organic hybrid material constructed from an "inverted Keggin" polyoxometalate and a copper (I)-organic complex. Inorg. Chem. 2011, 50, 8967-8972. [CrossRef] [PubMed]

77. Hu, Y.; Luo, F.; Dong, F.F. Design synthesis and photocatalytic activity of a novel lilac-like silver-vanadate hybrid solid based on dicyclic rings of $\left[\mathrm{V}_{4} \mathrm{O}_{12}\right]^{4-}$ with $\left\{\mathrm{Ag}_{7}\right\}^{7+}$ cluster. Chem. Commun. 2011, 47, 761-763. [CrossRef] [PubMed]

78. Kan, W.Q.; Liu, B.; Yang, J.; Liu, Y.Y.; Ma, J.F. Series of Highly Connected Metal-Organic Frameworks Based on Triangular Ligands and $\mathrm{d}^{10}$ Metals: Syntheses, Structures, Photoluminescence, and Photocatalysis. Cryst. Growth Des. 2012, 12, 2288-2298. [CrossRef]

79. Fu, H.; Li, Y.G.; Lu, Y.; Chen, W.L.; Wu, Q.; Meng, J.X.; Wang, X.L.; Zhang, Z.M.; Wang, E.B. Polyoxometalate-based metal-organic frameworks assembled under the ionothermal conditions. Cryst. Growth Des. 2011, 11, 458-465. [CrossRef]

80. Wu, Q.; Chen, W.L.; Liu, D.; Liang, C.; Li, Y.G.; Lin, S.W.; Wang, E.B. New class of organic-inorganic hybrid aggregates based on polyoxometalates and Metal-Schiff-base. Dalton Trans. 2011, 40, 56-61. [CrossRef] [PubMed]

81. Hu, M.Q.; Xu, Y.M. Photocatalytic degradation of textile dye $\mathrm{X}_{3} \mathrm{~B}$ by heteropolyoxometalate acids. Chemosphere 2004, 54, 431-434. [CrossRef]

82. Lv, K.L.; Xu, Y.M. Effects of Polyoxometalate and Fluoride on Adsorption and Photocatalytic Degradation of Organic Dye $\mathrm{X} 3 \mathrm{~B}$ on $\mathrm{TiO}_{2}$ : The Difference in the Production of Reactive Species. J. Phys. Chem. B 2006, 110, 6204-6212. [CrossRef] [PubMed]

83. Wen, L.L.; Zhao, J.B.; Lv, K.L.; Wu, Y.H.; Deng, K.J.; Leng, X.K.; Li, D.F. Visible-light-driven photocatalysts of metal-organic frameworks derived from multi-carboxylic acid and imidazole-based spacer. Cryst. Growth Des. 2012, 12, 1603-1612. [CrossRef] 